\title{
PENGEMBANGAN MODUL KIMIA DASAR BERBASIS MULTIPEL LEVEL REPRESENTASI UNTUK MENINGKATKAN KEMAMPUAN BERPIKIR KRITIS MAHASISWA
}

\author{
Atik Rahmawati \\ Fakultas Sains dan Teknologi, UIN Walisongo
}

\begin{abstract}
Abstrak
Rendahnya kemampuan mahasiswa yang mengikuti kuliah Kimia Dasar dalam merepresentasikan konsep-konsep kimia pada keempat level representasi kimia, serta belum tersedianya bahan ajar yang merepresentasikan konsep-konsep kimia pada keempat level representasi, mendorong peneliti untuk mengembangkan modul Kimia Dasar berbasis multipel level representasi kimia. Tujuan dari penelitian ini adalah : a. Bagaimana desain dan sistematika modul kimia dasar berbasis multipel level representasi kimia pada materi stoikiometri untuk meningkatkan kemampuan berpikir kritis mahasiswa? b. Bagaimana kelayakan modul kimia dasar berbasis multipel level representasi kimia, ditinjau dari validasi ahli?

Jenis penelitian ini adalah penelitian dan pengembangan. Model pengembangan mengikuti model Thiagarajan 4-D yang memiliki 4 tahap utama yaitu Define, Design, Develop, dan Disseminate.

Hasil penelitian dan pengembangan telah dihasilkan Modul Kimia Dasar berbasis Multipel Level Representasi dengan susunan sebagai berikut : cover, petunjuk penggunaan modul, tujuan pembelajaran, Kegiatan Belajar 1 (meliputi materi konsep massa atom, massa atom relatif rata-rata dan massa molekul relatif rata-rata; persamaan reaksi kimia; konsep mol; persen komposisi senyawa; penentuan rumus empiris dan rumus molekul; pereaksi pembatas; dan persen hasil). Pada Kegiatan Belajar 2 materinya meliputi larutan, konsentrasi larutan, pembuatan kelarutan dengan kemolaran tertentu, pengenceran larutan, stoikiometri larutan (analisis gravimetri, titrasi asam-basa). Setiap materi dilengkapi dengan contoh soal, latihan yuk, dan uji kompetensi. Modul dilengkapi dengan gambar yang dapat menjelaskan konsep kimia skala makroskopis pada level mikroskopis dan simbolis, serta interkoneksi antar ketiga level representasi kimia tersebut sehingga dapat meningkatkan kemampuan berpikir kritis mahasiswa.

Penilaian kelayakan (validasi) modul kimia dasar berbasis multipel level representasi kimia oleh ahli menunjukkan bahwa draft modul dalam kategori sangat baik dan baik sehingga tidak perlu dilakukan revisi.
\end{abstract}

Kata kunci: modul kimia dasar, multipel level representasi, berpikir kritis

\section{PENDAHULUAN}

Ilmu kimia merupakan ilmu yang diperoleh dan dikembangkan berdasarkan eksperimen yang mencari jawaban atas pertanyaan apa, mengapa, dan bagaimana gejala-gejala alam; khususnya yang berkaitan dengan komposisi, struktur dan sifat, transformasi, dinamika, dan energetika zat. Ilmu kimia mempelajari bangun (struktur) materi dan perubahan-perubahan yang dialami materi baik dalam proses-proses alamiah maupun dalam eksperimen yang direncanakan. Melalui kimia kita mengenal susunan (komposisi) zat baik alamiah maupun buatan, dan mengenal proses-proses penting dalam benda hidup, termasuk tubuh kita sendiri.

Penjelasan konsep-konsep kimia pada umumnya berlandaskan struktur materi dan ikatan kimia yang merupakan subyek yang tidak mudah untuk dipelajari. Konsep-konsep abstrak tersebut sangat 
penting dipelajari karena konsep-konsep kimia selanjutnya akan sulit dipahami, jika konsep sebelumnya tidak dikuasai dengan baik. Keabstrakan konsep-konsep kimia tersebut menjadikan kesulitan bagi siswa dan juga guru di dalam membelajarkan kimia, sebagaimana hasil penelitian Treagust and Chittleborough, 2001 dalam Chandrasagaran AL dkk., 2008. Akibatnya siswa cenderung untuk membawa pandangan tersendiri tentang fenomena ilmiah dan pengalaman yang telah mereka miliki. Konsepsi unik tentang fenomena alam yang dimiliki siswa sering resisten terhadap pengajaran karena konsepsi ini telah tertanam kuat dalam pikiran siswa, terutama konsepsi yang diperoleh siswa dari pengalaman sehari-hari. Selain itu, sifat keabstrakan konsep-konsep kimia juga sejalan dengan konsep-konsep yang melibatkan perhitungan matematis. Hal ini menunjukkan bahwa pembelajaran kimia memerlukan seperangkat keterampilan berpikir tingkat tinggi dan salah satunya adalah kemampuan berpikir kritis.

Untuk memahami ilmu kimia secara komprehensif, sesungguhnya terdapat 4 aspek representasi yang harus dikuasai. Keempat aspek tersebut adalah aspek makroskopik (fenomena yang dapat diamati), aspek mikroskopik (penggunaan diagram atau gambar yang menunjukkan fenomena di tingkat molekuler atau atom, ion), aspek simbolik (penggunaan persamaan kimia serta lambanglambang kimia untuk menggambarkan suatu fenomena) dan aspek matematik (perhitungan matematis yang menyertai suatu fenomena) (Rahayu 2002:277).

Ainsworth (dalam Treagust, 2008) menyatakan multipel representasi dapat berfungsi sebagai instrumen yang memberikan dukungan dan memfasilitasi terjadinya belajar bermakna (meaningful learning) dan/atau belajar yang mendalam (deep learning) pada pebelajar. Multipel representasi juga merupakan alatyang memiliki kekuatan untuk menolong pebelajar mengembangkan pengetahuan ilmiahnya.

Kebermaknaan belajar dapat direfleksikan dengan kemampuan pebelajar dalam memecahkan masalah. Kemampuan pemecahan masalah merupakan salah satu keterampilan berpikir tingkat tinggi menggunakan kompetensi representasi (representational competence) secara ganda (multiple) atau kemampuan pembelajar 'bergerak' diantara berbagai level representasi (Kozma, 2005).

Secara umum, pembelajaran kimia hanya membatasi pada dua level representasi, yaitu makroskopik dan simbolik. Hal ini menjadikan sebagian besar pebelajar tidak mampu menjelaskan konsep-konsep kimia pada skala mikroskopis. Selain itu, sebagian besar peserta didik lebih banyak belajar memecahkan soal matematis tanpa mengerti dan memahami maksudnya.

Sebagian pendidik beranggapan keberhasilan peserta didik dalam memecahkan soal matematis mengindikasikan peserta didik telah memahami konsep kimia. Padahal, banyak peserta didik yang berhasil memecahkan soal matematis tetapi tidak memahami konsep kimianya, karena hanya menghafal rumus. Kecenderungan ini juga kami temui pada mahasiswa Tadris Kimia, utamanya mahasiswa tingkat awal yang menempuh kuliah Kimia Dasar. 
Sebagian besar mahasiswa kimia dapat menjelaskan konsep makroskopis, tetapi tidak mampu menjelaskan pada skala mikro. Hal ini peneliti temukan pada saat mahasiswa pada konsep mol. Ada beberapa mahasiswa berpendapat bahwa mol merupakan massa dalam satuan gram dibagi dengan massa atom relatif atau massa molekul relatif. Dan pendapat ini disepakati oleh sebagian besar mahasiswa (lebih dari 85\%). Sebagian kecil berpendapat bahwa mol merupakan molaritas kali volume, tanpa memahami apakah volume pelarut atau larutan. Pada pendapat pertama, menunjukkan bahwa mahasiswa belum paham bahwa massa atom atau molekul dalam satuan gram berarti entitas atom atau molekul dalam skala besar (makroskopis), sedangkan massa atom atau massa molekul relatif adalah entitas atom atau molekul dalam skala yang sangat kecil (mikroskopis). Sedangkan pada pendapat kedua, menunjukkan bahwa mahasiswa belum memahami konsep mol, mereka masih sebatas menghafal rumus tanpa mengetahui maknanya. Adanya temuan ini menunjukkan bahwa mahasiswa belum dapat memahami entitas dasar (atom, molekul, ion) pada skala mikroskopis, makroskopis, dan simbolis. Hal ini mengakibatkan sebagian mahasiswa mengalami miskonsepsi pada konsep-konsep dasar kimia.

Sebagian besar mahasiswa yang cenderung hanya menghafalkan representasi sub makroskopik dan simbolik yang bersifat abstrak (dalam bentuk deskripsi kata-kata), mengakibatkan ketidakmampuan dalam membayangkan bagaimana proses dan struktur dari suatu zat yang mengalami reaksi. Oleh karena itu, untuk memahami ilmu kimia secara komprehensif sangat penting pemahaman keempat level representasi kimia.

Berdasarkan pengamatan, buku teks yang digunakan sebagian besar mahasiswa Tadris Kimia belum merepresentasikan keempat level representasi kimia, terutama pada level mikroskopis. Oleh karena itu peneliti menganggap penting untuk melakukan penelitian dan pengembangan modul Kimia Dasar berbasis multipel level representasi pada materi pokok stoikiometri. Penelitian ini diharapkan mampu memberikan kontribusi nyata terhadap perkuliahan Kimia Dasar di Jurusan Pendidikan Kimia, Fakultas Ilmu Tarbiyah dan Keguruan UIN Walisongo Semarang. Modul ini penting untuk membantu dan memandu mahasiswa dalam pembelajaran sekaligus sebagai pengayaan materi Kimia Dasar.

\section{METODE PENELITIAN}

Metode penelitian ini adalah penelitian dan pengembangan $(R n D)$. Menurut Gay (1990) penelitian pengembangan adalah suatu usaha untuk mengembangkan suatu produk yang efektif. Dalam pelaksanaan penelitian dan pengembangan terdapat beberapa metode yang digunakan yaitu metode penelitian deskriptif, evaluatif dan eksperimental.

Model pengembangan yang digunakan dalam penelitian ini mengikuti alur dari Sivasailam Thiagarajan, Dorothy S. Semmel, dan Melvyn I. Semmel (1974). Model pengembangan 4-D memiliki 
4 tahap utama yaitu Define, Design, Develop, dan Disseminate. Model pengembangan 4D jika diadaptasikan menjadi model 4-P, yaitu pendefinisian, perancangan, pengembangan, dan penyebaran. Dalam penelitian dan pengembangan ini, dibatasi menjadi tiga tahap yaitu Define, Design, dan Develop. Pada tahap Develop (Pengembangan) dibatasi hanya pada validasi ahli.

Tahap define merupakan tahap untuk menetapkan dan mendefinisikan kebutuhan dalam pengembangan pembelajaran. Penetapan kebutuhan dilakukan dengan memperhatikanserta menyesuaikan kebutuhan pembelajaran untuk mahasiswa kimia yang menempuh kuliah Kimia Dasar I. Tahap define mencakup tiga langkah pokok, yaitu analisis ujung depan (front-end analysis), analisis peserta didik (learner analysis), dan analisis konsep (concept analysis).

\section{a. Analisis Ujung Depan (Front-End Analysis)}

Menurut Thiagarajan(1974:5) "Front-end analysis is the study of the basic problem facing the teacher trainer". Analisis ujung depan bertujuan untuk memunculkan dan menetapkan masalah dasar yang dihadapi dalam pembelajaran Kimia Dasar sehingga diperlukan suatu pengembangan bahan pembelajaran. Peneliti melakukan diagnosis awal untuk mengetahui kemampuan mahasiswa dalam memahami konsep-konsep kimia secara luas dan mendalam. Dengan analisis ini akan didapatkan gambaran fakta, harapan dan alternatif penyelesaian masalah dasar yang memudahkan dalam penentuan atau pemilihan media pembelajaran yang dikembangkan.

b. Analisis Peserta Didik (Learner Analysis)

Analisis peserta didik merupakan telaah tentang karakteristik mahasiswa yang sesuai dengan desain pengembangan perangkat pembelajaran. Analisis ini dilakukan untuk mendapatkan gambaran karakteristik Mahasiswa,

c. Analisis konsep (Concept Analysis)

Analisis konsep merupakan satu langkah penting untuk memenuhi prinsip dalam membangun konsep atas materi-materi yang digunakan sebagai sarana pencapaian kompetensi dasar dan standar kompetensi. Dalam mendukung analisis konsep ini, analisis yang dilakukan adalah (1) analisis standar kompetensi dan kompetensi dasar yang bertujuan untuk menentukan jumlah dan jenis bahan ajar, (2) analisis sumber belajar, yakni mengumpulkan dan mengidentifikasi sumber mana yang mendukung penyusunan bahan ajar.

Tahap berikutya adalah tahap perancangan yang bertujuan untuk merancang perangkat pembelajaran. Langkah yang dilakukan pada tahap ini, yaitu: (1) penyusunan standar tes (criterion-test construction), (2) pemilihan media (media selection) yang sesuai dengan karakteristik materi dan tujuan pembelajaran, (3) pemilihan format (format selection), yakni mengkaji format-format bahan ajar yang ada dan menetapkan format bahan ajar yang akan dikembangkan, dan (4) membuat rancangan awal (initialdesign) sesuai format yang dipilih. 
Tahap pengembangan adalah tahap untuk menghasilkan produk pengembangan yang dilakukan melalui dua langkah, yakni: (1) penilaian ahli (expert appraisal) yang diikuti dengan revisi, (2) uji coba pengembangan (developmental testing).

Subjek penelitian ini adalah mahasiswa Tadris Kimia Angkatan 2014/2015 Fakultas Ilmu Tarbiyah dan Keguruan IAIN Walisongo yang mengikuti mata kuliah Kimia Dasar I yaitu kelas TK 1A dan TK 1B.

Sumber data dari penelitian ini diperoleh dengan metode angket untuk mengetahui dan menganalisis gaya belajar mahasiswa dan kebutuhan belajar mahasiswa, serta validasi ahli.Pada kegiatan menganalisis gaya belajar dan kebutuhan belajar mahasiswa digunakan angket tertutup. Sedangkan pada validasi ahli digunakan angket terbuka.

Analisis data gaya belajar dan kebutuhan belajar mahasiswa, data dalam bentuk tabel skor dan saran dirangkum dan disimpulkan sehingga dapat dijadikan sebagai landasan untuk mengembangkan produk (modul).Demikian juga data yang diperoleh dari validasi ahli, juga akan diuraikan secara deskriptif. Validasi dari ahli dijadikan sebagai salah satu landasan dalam merevisi rancangan modul. Adapun rumus yang digunakan dalam penilaian ini sebagai berikut:

Keterangan:

$$
\mathrm{NP}=\frac{R}{S M} x 100
$$

$\mathrm{NP}=$ nilai persen yang dicari atau diharapkan

$\mathrm{R}=$ skor mentah penilaian validator

$\mathrm{SM}=$ skor maksimum ideal dari pernyataan

100 = Bilangan tetap

Sebagai ketentuan dalam memberikan makna dan pengambilan keputusan hasil perhitungan di atas dapat ditafsirkan dengan rentang seperti pada Tabel 1 berikut:

Tabel 1. Kategosasi Tingkat Pencapaian Produk

\begin{tabular}{|c|l|l|}
\hline $\begin{array}{c}\text { Tingkat } \\
\text { Pencapaian }\end{array}$ & \multicolumn{1}{|c|}{ Penafsiran } & \multicolumn{1}{|c|}{ Keterangan } \\
\hline $85-100 \%$ & Sangat baik & Tidak perlu revisi \\
\hline $75-84 \%$ & Baik & Tidak perlu revisi \\
\hline $60-74 \%$ & Cukup baik & Tidak perlu revisi \\
\hline $55-59 \%$ & Kurang & Perlu revisi \\
\hline$\leq 54 \%$ & Kurang sekali & Perlu revisi \\
\hline
\end{tabular}

\section{HASIL PENELITIAN DAN PEMBAHASAN}

Penelitian dan pengembangan ini mengikuti model pengembangan Sivasailam Thiagarajan, Dorothy S. Semmel, dan Melvyn I. Semmel (1974) yang terdiri 4 tahap utama yaitu Define, Design, Develop, dan Disseminate. Model pengembangan 4D diadaptasikan menjadi model 4-P, yaitu 
pendefinisian, perancangan, pengembangan, dan penyebaran. Tahapan penelitian dan pengembangan akan peneliti deskripsikan sesuai dengan tahapan di atas:

\section{Define (Pendefinisian)}

Tahap define merupakan tahap untuk menetapkan dan mendefinisikan kebutuhan dalam pengembangan pembelajaran. Penetapan kebutuhan dilakukan dengan memperhatikan serta menyesuaikan kebutuhan pembelajaran mahasiswa kimia yang menempuh kuliah Kimia Dasar I. Tahap define mencakup tiga langkah pokok, yaitu analisis ujung depan (front-end analysis), analisis peserta didik (learner analysis), dan analisis konsep (concept analysis).

\section{Analisis Ujung-Depan (front-end analysis)}

Analisis ini bertujuan untuk mengetahui permasalahan yang dihadapi pendidik (dosen) dan mahasiswa (pebelajar) pada perkuliahan Kimia Dasar I. Berdasarkan pengalaman peneliti selaku dosen pengampu mata kuliah Kimia Dasar I, bahwa ketercapaian kompetensi pada materi stoikiometri cukup rendah.Mahasiswa yang mencapai ketuntasan belajar pada materi stiokiometri hanya sekitar 10\%. Rendahnya pencapaian ini dipengaruhi oleh beberapa faktor, pengalaman mahasiswa di sekolah/madrasah sebelumnya yang belum memahami sepenuhnya konsep mol. Ketika peneliti bertanya pada mahasiswa tentang konsep mol, ada yang berpendapat bahwa mol sebagai hasil bagi dari gram dengan massa atom relatif rata-rata atau massa molekul relatif rata-rata. Pendapat ini didukung oleh lebih dari 50\% mahasiswa. Pendapat kedua menyatakan bahwa mol adalah hasil kali molaritas (M) dan Volume (V) atau dapat dinyatakan mol = MxV. Pendapat ketiga menyatakan bahwa mol merupakan volume dibagi 22,4L. Pada pendapat kedua dan ketiga juga dibenarkan oleh sebagian mahasiswa. Pada pendapat pertama ketika peneliti menanyakan satuan dari massa atom relatif rata-rata, mereka tidak mampu menjawab. Kemudian bagaimana massa (dalam satuan gram) dibagi Ar/Mr dapat memberikan satuan mol. Hal ini juga tidak dapat dijawab oleh satupun mahasiswa. Berdasarkan ketiga pendapat di atas, menunjukkan bahwa mahasiswa belum paham tentang konsep mol. Mereka menyatakan konsep mol berdasarkan hafalan persamaan mol di sekolah/madrasah, tanpa mereka paham tentang mol. Mahasiswa terindikasi mengalami miskonsepsi pada konsep mol. Hal ini selaras dengan temuan Rahmawati (2011) yang menganalisis miskonsepsi mahasiswa kimia tingkat dasar pada konsep mol. Miskonsepsi konsep mol diawali dari miskonsepsi satuan dari massa atom relatif rata-rata (Ar). Sebagian besar mahasiswa menganggap bahwa satuan dari Ar adalah gram(g). Hal ini mengakibatkan kemampuan mahasiswa dalam hitungan kimia sangat rendah.Terjadinya miskonsepsi mahasiswa pada konsep mol, kemungkinan besar disebabkan oleh miskonsepsi mereka di sekolah.Hal ini sesuai dengan hasil penelitian yang dilakukan oleh Meor Ibrahim bin Kamaruddin \& Nurhidayah binti Ismail dari Universitas Teknologi Malaysia (UTM) 
tentang miskonsepsi pelajar di Malaysia tentang konsep mol dan persamaan kimia. Hasil penelitian menunjukkan bahwa kebanyakan responden melihat mol sebagai kuantitas sesuatu bahan tetapi tidak jelas lagi bagaimana hubungannya dengan jumlah atom karbon-12 maupun bilangan Avogadro. Bagipelajar yang melihat 1 unit mol sebagai 1 unit massaatom relatif karbon-12, ini mungkinkarena pelajar sering menggunakan massa per $\mathrm{Ar}$ atau $\mathrm{Mr}$ dalam penyelesaian masalah yangmelibatkan konsep mol, dan kemungkinan juga ditambahdengan penganalogian yang kurang berhasil dariguruguru sendiri.

Berdasarkan kajian Rahmawati (2011) pada buku ajar kimia yang selama ini menjadi pegangan di sekolah-sekolah turut menyumbang terjadinya miskonsepsi pada konsep mol adalah.Berdasarkan 2 buku yang di observasi, hubungan antara mol dengan massa suatu unsur atau senyawa dan jumlah partikel dinyatakan sebagai:

$$
\mathrm{n} \mathrm{mol}=\frac{\text { a gram }}{\mathrm{Mr}} \text { atau a gram }=\mathrm{n} \times \mathrm{Mr}
$$

Kemampuan mahasiswa Tadris Kimia yang menempuh kuliah Kimia Dasar I dalam memahami materi yang bersifat makroskopis pada skala mikroskopis masih sangat rendah. Hal ini terbukti ketika peneliti menanyakan partikel apa yang terdapat dalam sejumlah air, sebagian mahasiswa menyatakan bahwa partikelnya adalah ion $\mathrm{H}^{+}$dan ion $\mathrm{OH}^{-}$, yang lainnya menyatakan atom $\mathrm{H}$ dan O. Demikian juga ketika peneliti menanyakan pada larutan asam asetat, partikel apa saja yang terdapat dalam larutan tersebut? Tidak ada mahasiswa yang mampu menjawab pertanyaan tersebut dengan tepat.Hal ini menunjukkan hampir semua mahasiswa belum mampu merepresentasikan aspek mikroskopis dan simbolis terhadap fenomena makroskopis.

\section{Analisis Peserta Didik}

Pada tahap ini, dilakukan analisis gaya belajar mahasiswa Tadris Kimia semester I dan analisis kebutuhan belajar peserta didik. Hasil penelitian analisis gaya belajar mahasiswa Tadris Kimia yang mengikuti perkuliahan Kimia dasar I ditunjukkan pada Tabel 2 berikut:

Tabel 2. Gaya Belajar MahasiswaTadris Kimia

\begin{tabular}{|c|l|l|}
\hline No & \multicolumn{1}{|c|}{ Gaya Belajar } & Persentase (\%) \\
\hline 1 & Tipe visual & $54,5 \%$ \\
\hline 2 & Tipe Auditory & $24,2 \%$ \\
\hline 3 & Tipe Kinestetik & $21,3 \%$ \\
\hline
\end{tabular}

Berdasarkan Tabel 1 diketahui bahwa gaya belajar mahasiswa sebagian besar adalah visual. Seseorang dengan tipe atau gaya belajar visual, media atau sumber belajar yang cocok adalah modul 
atau buku yang banyak mencantumkan diagram atau gambar. Dengan demikian modul ini banyak dilengkapi dengan gambar, selain dapat merepresentasikan ketiga level representasi kimia, juga sesuai dengan gaya belajar mahasiswa.

Sedangkan tempat yang paling disukai atau sering digunakan mahasiswa untuk belajar ditunjukkan pada Tabel 3 berikut:

Tabel 3 Tempat Belajar Mahasiswa

\begin{tabular}{|c|l|l|}
\hline No & \multicolumn{1}{|c|}{ Tempat Belajar } & $\begin{array}{c}\text { Persentase } \\
(\mathbf{\%})\end{array}$ \\
\hline 1 & Rumah/kos & $73 \%$ \\
\hline 2 & Perpustakaan & $18 \%$ \\
\hline 3 & Kelas & $6 \%$ \\
\hline 4 & Taman & $6 \%$ \\
\hline 5 & Tempat lain & $6 \%$ \\
\hline
\end{tabular}

Berdasarkan Tabel 3 di atas, sebagian besar mahasiswa memilih rumah/kos sebagai tempat belajar, sementara perpustakaan hanya sebesar $18 \%$.Hal ini mungkin disebabkan karena kekurangnyamanan perpustakaan sebagai tempat belajar akibat dari kurang proporsionalnya luas perpustakaan dengan jumlah mahasiswa Fakultas Ilmu Tarbiyah dan Keguruan.Dengan demikian dapat dinyatakan bahwa diperlukan media atau sumber belajar yang memungkinkan mahasiswa belajar secara mandiri.

Untuk sumber belajar, sebagian besar mahasiswa memanfaatkan internet, sebagian menyatakan dosen sebagai sumber belajar. Hasil selengkapnya tentang sumber belajar ditunjukkan pada Tabel 4 berikut:

Tabel 4 Sumber Belajar Mahasiswa

\begin{tabular}{|c|l|l|}
\hline No & Sumber Belajar & Persentase (\%) \\
\hline 1 & Buku & $55 \%$ \\
\hline 2 & Modul & $64 \%$ \\
\hline 3 & Internet & $79 \%$ \\
\hline 4 & Dosen & $67 \%$ \\
\hline
\end{tabular}

Berdasarkan data pada Tabel 4, mahasiswa lebih memilih modul sebagai sumber belajar dibandingkan dengan buku. Namun demikian modul yang mereka gunakan belum merepresentasikan level makroskopis, mikroskopis, dan simbolis, serta belum mengkoneksikan antar ketiga level tersebut. Hal ini tercermin dari kebutuhan mahasiswa akan modul yang mampu merepresentasikan level makroskopis, mikroskopis, dan simbolis sebanyak 94\%. Untuk merepresentasikan ketiga level tersebut mahasiswa mengusulkan konten tambahan berupa gambar sebesar $91 \%$, foto sebesar $67 \%$, dan grafik/tabel sebesar $76 \%$. 
Demikian juga dengan buku teks yang tersedia, sebagian besar merupakan buku terjemahan yang sebagian konteks sulit dipahami.Akibatnya sebagian mahasiswa ada yang masih menggunakan LKS semasa sekolah karena bahasanya yang mudah dipahami meskipun pengetahuannya kurang luas dan mendalam.

\section{Analisis Konsep}

Analisis terakhir dari tahap pendefinisian adalah analisis konsep atau kurikulum. Berikut adalah standar kompetensi, kompetensi dasar, indikator, dan materi:

\section{Standar Kompetensi:}

Mahasiswa dapat menjelaskan dan menerapkan konsep stoikiometri, prinsip-prinsip termodinamika, struktur atom, sistem periodik unsur, ikatan kimia, geometri molekul, kesetimbangan kimia, serta gaya antar molekul yang merupakan landasan untuk mempelajari ilmu kimia lanjut.

\section{Kompetensi Dasar:}

1. Mahasiswa dapat menjelaskan konsep stoikiometri dan mengaplikasikannya pada reaksi-reaksi kimia

\section{Indikator:}

1. Menentukan massa atom relatif rata-rata (Ar) suatu atom dan massa molekul relatif rata-rata (Mr) suatu senyawa.

2. Menyetarakan suatu persamaan reaksi kimia lengkap dengan fasanya

3. Merumuskan hubungan konsep mol dengan jumlah partikel dan massa suatu zat.

4. Menyelesaikan hitungan-hitungan kimia dengan konsep mol.

5. Menentukan rumus empiris dan rumus molekul suatu zat berdasarkan data percobaan.

6. Menentukan pereaksi pembatas dari suatu reaksi kimia.

7. Menghitung persen hasil suatu reaksi kimia.

Berdasarkan indikator di atas, maka materi yang dikembangkan adalah konsep massa atom, massa atom relatif rata-rata dan massa molekul relatif rata-rata; persamaan reaksi kimia; konsep mol; persen komposisi senyawa; penentuan rumus empiris dan rumus molekul; pereaksi pembatas; dan persen hasil.

\section{Kompetensi Dasar:}

2. Mahasiswa dapat menjelaskan konsep larutan dan menerapkannya pada reaksi-reaksi kimia.

\section{Indikator:}

1. Menjelaskan terjadinya proses pelarutan baik pada skala makroskopis maupun mikroskopis.

2. Menghitung konsentrasi larutan berair dengan satuan molaritas.

3. Membuat larutan dengan kemolaran tertentu baik dari zat padat maupun dari larutan dengan konsentrasi yang lebih pekat berikut cara kerjanya.

4. Menghitung persen massa suatu zat dalam sampel berdasarkan reaksi pengendapan. 
5. Menjelaskan konsep titrasi asam asam-basa dan memilih indikator dengan tepat.

6. Menghitung konsentrasi suatu zat berdasarkan titrasi asam-basa.

Berdasarkan indikator di atas, maka materi yang dikembangkan adalah larutan, konsentrasi larutan, pembuatan kelarutan dengan kemolaran tertentu, pengenceran larutan, stoikiometri larutan (analisis gravimetri, titrasi asam-basa).

\section{Design (Perancangan)}

Tahap perancangan dilakukan setelah dilakukan tahapan define (pendefinisian). Berdasarkan analisis kebutuhan pada tahap define, maka rancangan modul disusun dengan memperhatikan gaya belajar mahasiswa, kebutuhan modul yang dapat merepresentasi ketiga level representasi kimia (skala makroskopis, mikroskopis, dan simbolik), dan materi yang dikembangkan berdasarkan indikator. Pada modul dilengkapi dengan gambar yang dapat merepresentasikan level mikroskopis maupun simbolis.

Rancangan awal (draft) modul Kimia Dasar berbasis Multipel Level Representasi Kimia meliputi: cover, petunjuk penggunaan modul, tujuan pembelajaran, Kegiatan Belajar 1 (meliputi materi konsep massa atom, massa atom relatif rata-rata dan massa molekul relatif rata-rata; persamaan reaksi kimia; konsep mol; persen komposisi senyawa; penentuan rumus empiris dan rumus molekul; pereaksi pembatas; dan persen hasil), setiap materi dilengkapi dengan contoh soal, latihan yuk, terakhir uji kompetensi. Pada Kegiatan Belajar 2 materinya meliputi larutan, konsentrasi larutan, pembuatan kelarutan dengan kemolaran tertentu, pengenceran larutan, stoikiometri larutan (analisis gravimetri, titrasi asam-basa). Setiap materi dilengkapi dengan contoh soal, latihan yuk, dan uji kompetensi.

\section{Develop (Pengembangan)}

Tahap pengembangan adalah tahap untuk menghasilkan produk pengembangan yang dilakukan melalui dua langkah, yakni: (1) penilaian ahli (expert appraisal) yang diikuti dengan revisi, (2) uji coba pengembangan (developmental testing). Namun demikian pada tahap ini dibatasi pada penilaian ahli (validasi ahli). Validasi ahli dilakukan oleh dosen pengampu mata kuliah Kimia Dasar yaitu ibu Wirda Udaibah, M.Si yang selanjutnya disebut validator 1 dan ibu Dina Sugiyanti, M.Si sebagai validator 2. Tabel 5 berikut merupakan hasil rekapitulasi validator: Tabel 5. Hasil Validasi Ahli

\begin{tabular}{|l|l|c|c|}
\hline No & \multicolumn{1}{|c|}{ Aspek } & Validator I & Validator II \\
\hline 1 & Adanya petunjuk penggunaan modul & 4 & 3 \\
\hline 2 & Adanya tujuan pembelajaran & 4 & 3 \\
\hline
\end{tabular}




\begin{tabular}{|c|c|c|c|}
\hline 3 & Sistematika penyajian materi & & \\
\hline & a. Stoikiometri & 4 & 3 \\
\hline & b. Stoikiometri larutan & 3 & 3 \\
\hline 4 & Ketepatan materi dengan indikator: & & \\
\hline & a. Stoikiometri & 3 & 4 \\
\hline & b. Stoikiometri larutan & 4 & 3 \\
\hline 5 & Merangsang keingintahuan & & \\
\hline & a. Menumbuhkan rasa ingin tahu & 3 & 3 \\
\hline & b. Mendorong untuk mencari informasi lebih lanjut & 2 & 3 \\
\hline 6 & Tata Bahasa & & \\
\hline & a. Pesan yang disampaikan mudah dipahami & 3 & 3 \\
\hline & b. Struktur kalimat efektif & 4 & 3 \\
\hline 7 & Penyajian materi & & \\
\hline & a. Keruntutan kajian konsep & 4 & 4 \\
\hline & $\begin{array}{l}\text { b. Kecukupan penjelasan materi pada skala } \\
\text { makroskopis, mikroskopis, dan simbolis }\end{array}$ & 3 & 3 \\
\hline & $\begin{array}{l}\text { c. Kesesuaian gambar, teks dengan materi pada skala } \\
\text { makroskopis, mikroskopis, dan simbolis }\end{array}$ & 4 & 4 \\
\hline 8 & Penyajian pembelajaran & & \\
\hline & a. Berpusat pada peserta didik & 3 & 3 \\
\hline & $\begin{array}{l}\text { b. Merangsang keterlibatan peserta didik untuk } \\
\text { belajar secara mandiri }\end{array}$ & 4 & 3 \\
\hline & c. Merangsang peserta didik berpikir kritis & 3 & 3 \\
\hline 9 & $\begin{array}{l}\text { Kecukupan tugas untuk mendorong peserta didik } \\
\text { belajar aktif }\end{array}$ & & \\
\hline & a. Stoikiometri & 3 & 2 \\
\hline & b. Stoikiometri larutan & 3 & 3 \\
\hline 10 & $\begin{array}{l}\text { Kesesuaian instrumen penilaian dengan tujuan } \\
\text { pembelajaran }\end{array}$ & 4 & 3 \\
\hline 11 & $\begin{array}{l}\text { Instrumen penilaian mendorong peserta didik berpikir } \\
\text { kritis }(\mathrm{C} 3, \mathrm{C} 4, \mathrm{C} 5)\end{array}$ & 3 & 3 \\
\hline & $\begin{array}{l}\text { Jumlah } \\
\text { Persentase } \\
\text { Keterangan }\end{array}$ & \begin{tabular}{l}
\multicolumn{1}{c}{68} \\
\multicolumn{1}{c}{$85 \%$} \\
Sangat baik, \\
tidak perlu \\
revisi modul \\
\end{tabular} & \begin{tabular}{l}
$\quad \quad 62$ \\
\multicolumn{1}{c}{$77,5 \%$} \\
Baik, tidak \\
perlu revisi \\
modul
\end{tabular} \\
\hline
\end{tabular}

Berdasarkan hasil validasi ahli I dan II sebagaimana tertera pada Tabel 5, dapat disimpulkan bahwa draft modul dalam kategori sangat baik dan baik sehingga tidak perlu dilakukan revisi. Namun demikian pada aspek mendorong untuk mencari informasi lebih lanjut menurut validator I kategorinya cukup, sementara aspek lain pada kategori baik dan sangat baik. Sedangkan menurut validator II, aspek yang nilainya cukup adalah kecukupan tugas untuk mendorong peserta didik belajar aktif pada bagian stoikiometri, sementara aspek lain pada kategori baik dan sangat baik. Dengan adanya penilaian ini, menurut peneliti dalam implementasi modul masih perlu diberikan tugas tambahan dari pengampu.

Mengacu pada kebutuhan mahasiswa terhadap modul yang dilengkapi dengan gambar yang mampu merepresentasikan ketiga level representasi kimia, validator I dan II memberikan penilaian 
baik dan sangat baik. Dengan demikian draft modul ini layak untuk digunakan oleh mahasiswa sebagai salah satu sumber dan media belajar yang mampu mengkoneksikan ketiga level representasi kimia yang akhirnya mampu meningkatkan kemampuan berpikir kritis mahasiswa.

Namun demikian pada tahap ini masih perlu dilakukan uji keefektifannya dalam meningkatkan kemampuan berpikir kritis mahasiswa, yang dapat dilakukan pada penelitian lebih lanjut. Demikian pula tanggapan mahasiswa sebagai pengguna atas draft modul ini masih sangat diperlukan, sehingga perlu dilakukan penelitian lebih lanjut.

\section{KESIMPULAN}

Berdasarkan hasil penelitian dan pembahasan, dapat disimpulkan sebagai berikut:

1. Modul Kimia Dasar berbasis Multipel Level Representasi memiliki susunan sebagai berikut: cover, petunjuk penggunaan modul, tujuan pembelajaran, Kegiatan Belajar 1 (meliputi materi konsep massa atom, massa atom relatif rata-rata dan massa molekul relatif rata-rata; persamaan reaksi kimia; konsep mol; persen komposisi senyawa; penentuan rumus empiris dan rumus molekul; pereaksi pembatas; dan persen hasil), setiap materi dilengkapi dengan contoh soal, latihan yuk, terakhir uji kompetensi. Pada Kegiatan Belajar 2 materinya meliputi larutan, konsentrasi larutan, pembuatan kelarutan dengan kemolaran tertentu, pengenceran larutan, stoikiometri larutan (analisis gravimetri, titrasi asam-basa). Setiap materi dilengkapi dengan contoh soal, latihan yuk, dan uji kompetensi. Modul dilengkapi dengan gambar yang dapat menjelaskan konsep kimia skala makroskopis pada level mikroskopis dan simbolis, serta interkoneksi antar ketiga level representasi kimia tersebut sehingga dapat meningkatkan kemampuan berpikir kritis mahasiswa.

2. Penilaian kelayakan (validasi) modul kimia dasar berbasis multipel level representasi kimia oleh ahli menunjukkan bahwa draft modul dalam kategori sangat baik dan baik sehingga tidak perlu dilakukan revisi. 


\section{DAFTAR PUSTAKA}

Davidowitz B. \& Chittleborough, G. D. (2009). Linking the Macroscopic and Sub-microscopic Levels : Diagram. In: J. Gilbert \& D. Treagust (Eds.). Multiple Representation in Chemical Education: Models and Modeling in Science Education. Dordrecht: Springer. 169-191.

Farida, Ida. 2012. Interkoneksi Multipel Level Representasi Mahasiswa Calon Guru pada Kesetimbangan dalam Larutan melalui Pembelajaran Berbasis Web. Disertasi: Universitas Pendidikan Indonesia

Gilbert, J.K. \& Treagust, D.F., 2009, Introduction: Macro, sub-micro and symbolic representations and the relationship between them: Key models in chemical education. In: J. K. Gilbert \& D. Treagust (Eds.). Multiple Representations in Chemical Education: Models and Modeling in Science Education. Dordrecht: Springer.1-8

Kozma, R., \& Joel Russell. (2005). Modeling Students Becoming Chemists: Developing Representational Competence. In J. Gilbert (Ed.), Visualization in Science Education. Dordrecht: Springer. pp. 121-145

Mayangsari Vanny, dkk., http://jurnal-online.um.ac.id.

Meor Ibrahim bin Kamaruddin \& Nurhidayah binti Ismail, Miskonsepsi Pelajar Terhadap Konsep Mol dan Konsep Persamaan Kimia, Jurnal Penelitian. http://typecat.com/MISKONSEPSIPELAJAR-TERHADAP-KONSEP-MOL-DAN-KONSEP-PERSAMAAN-KIMIA

Rahmawati, Atik. 2011. Miskonsepsi Mahasiswa Tadris Kimia Tingkat Dasar pada Materi

Konsep Mol. Makalah disampaikan pada Diskusi Dosen Fakultas Tarbiyah pada tanggal 23 Maret 2011

Sugiyono, S., 2011, Metode Penelitian Kuantitatif, Kualitatif, dan R \& D, Bandung: Alfabeta

Thiagarajan, 1974. Instructional Development for Training Teachers of Exceptional Children A sourcebook, Indiana University. Bloomington: Indiana.

Utomo Widi Agung, dkk., 2013, Pengembangan Buku Ajar Materi Partikel berbasis Representasi Kimia, Jurnal Pendidikan Kimia Vol. 1 No. 9 